Prepared as part of the Department of the Interior Critical Ecosystems Studies Initiative and the U.S. Geological Survey Priority Ecosystems Science Initiative

\title{
Hydrologic Conditions in the Florida Panther National Wildlife Refuge, 2006-07
}

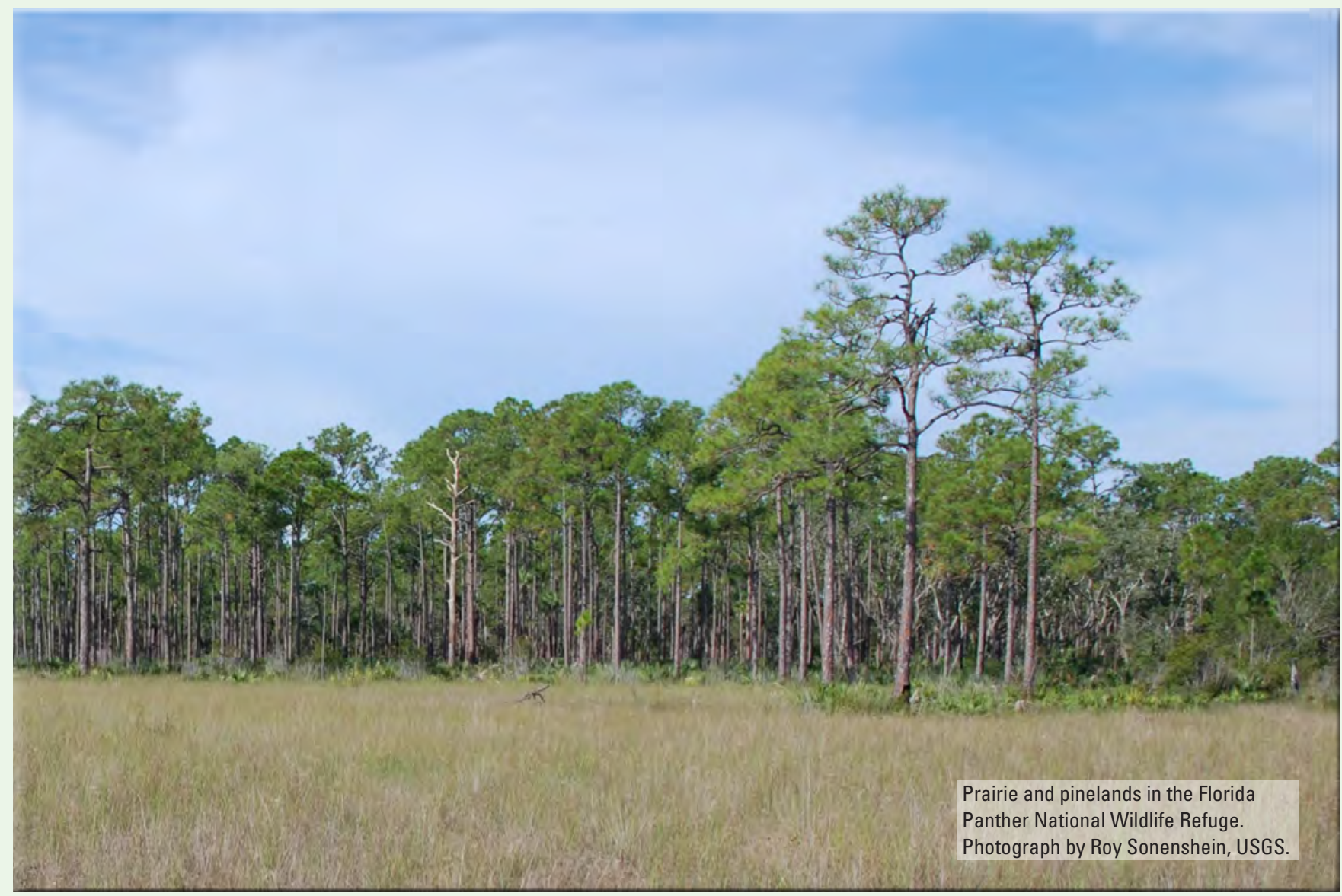

Much of the surface water that flows into the Florida Panther National Wildlife Refuge (FPNWR) probably exits southward through Fakahatchee Strand as it did prior to development, because culverts and bridges constructed along I-75 allow overland flow to continue southward within the strand. During the dry season and periods of low water levels, however, much of the flow is diverted westward by the I-75 Canal into Merritt Canal at the southwestern corner of the FPNWR. Substantial drainage of groundwater from the FPNWR into the I-75 Canal is indicated by (1) greater surface-water outflows than inflows in the FPNWR, (2) flows that increase to the west along the I-75 Canal, and (3) correlation of rapid groundwater-level declines at sites close to the I-75 Canal with rapid declines in canal surface-water levels due to operation of a control structure in the Merritt Canal. This drainage of groundwater probably occurs through permeable limestone exposed in the I-75 Canal bank below a cap rock layer.

Compared to predevelopment conditions, the time currently required to drain ponded water in some areas of the refuge should be less because of accelerated groundwater discharge into the I-75 Canal caused by the lowering of water levels in the canal during the peak of the wet season extending into the early dry season. This drainage probably reduces the duration of the hydroperiod in these wetlands from the wet season into the dry season, possibly reducing or limiting the extent or vitality of wildlife and plant community habitats. 


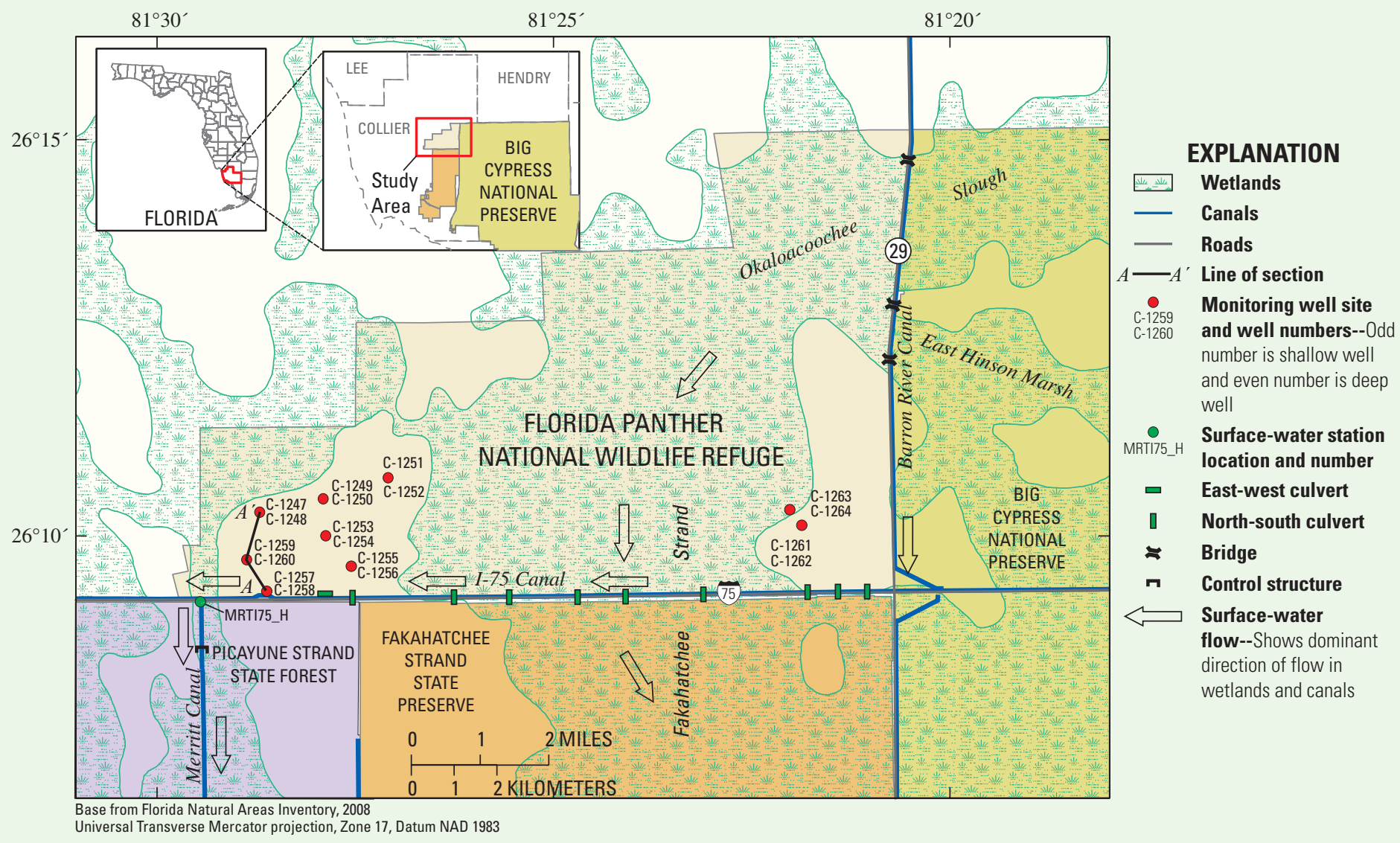

Figure 1. Location of study area, groundwater monitoring wells, and surface-water station.

\section{Introduction}

Historically, surface water flowed unimpeded to the southwest and south through the area now occupied by the Florida Panther National Wildlife Refuge (FPNWR) in southwestern Florida (fig. 1). This flow pattern has been altered by highway and canal construction along the eastern and southern boundaries of the FPNWR (fig. 1), and these changes have adversely affected the biological communities in the FPNWR and in adjacent preserves to the east and south. Urban and agricultural areas that border the northern and western sides of the FPNWR limit the extent of available wildlife habitat, and low water levels in wetlands and the shallow aquifer during the dry season may further reduce or limit the extent or vitality of wildlife and plant community habitats.

As part of the U.S. Department of the Interior Critical Ecosystems Studies Initiative and the U.S. Geological Survey Priority Ecosystems Science Initiative, a 2-year study was begun in October 2005 to document hydrologic conditions in the FPNWR, including groundwater levels and surface-water flow. The objectives of the study were to determine (1) how surface-water and groundwater levels are affected by the adjacent canals and highways, and (2) how surface-water and groundwater interactions are controlled by the shallow hydrogeology. Results from the study will help address science and management goals relevant to the preservation or restoration of the FPNWR.

\section{Methods}

A hydrologic monitoring well network designed and installed as part of the study included nine well clusters, each consisting of a shallow (odd numbered) and deep (even numbered) monitoring well. The wells were constructed in accessible southwestern and southeastern areas of the refuge that are usually dry or near the edge of wetland areas (fig. 1). Continuous core samples were collected and described from the deep well, drilled to a depth of
10 feet (ft), at eight of the nine sites. The shallow wells were constructed above a shallow confining layer and included a screened open interval no more than $2.5-\mathrm{ft}$ thick, with the bottom of the interval and the well ranging from 1.5 to $3 \mathrm{ft}$ below land surface. The deep wells extended below the confining layer and included a screened interval open from 7.5 to $10 \mathrm{ft}$ below land surface.

Submersible pressure transducers were installed in the deep wells at all sites in 2006 and 2007, and water levels were recorded hourly. All sites were surveyed using a Global Positioning System (GPS) to establish the land-surface and top of well casing altitudes relative to the North American Vertical Datum of 1988 (NAVD 88). Three of the nine deep wells (C-1248, C-1256 and C-1258) yielded hydrologic record spanning the entire August 2006 to November 2007 period analyzed for this study. Continuous data collection also began in August 2006 in C-1252, but the transducer in this well failed in May 2007 and was not replaced 


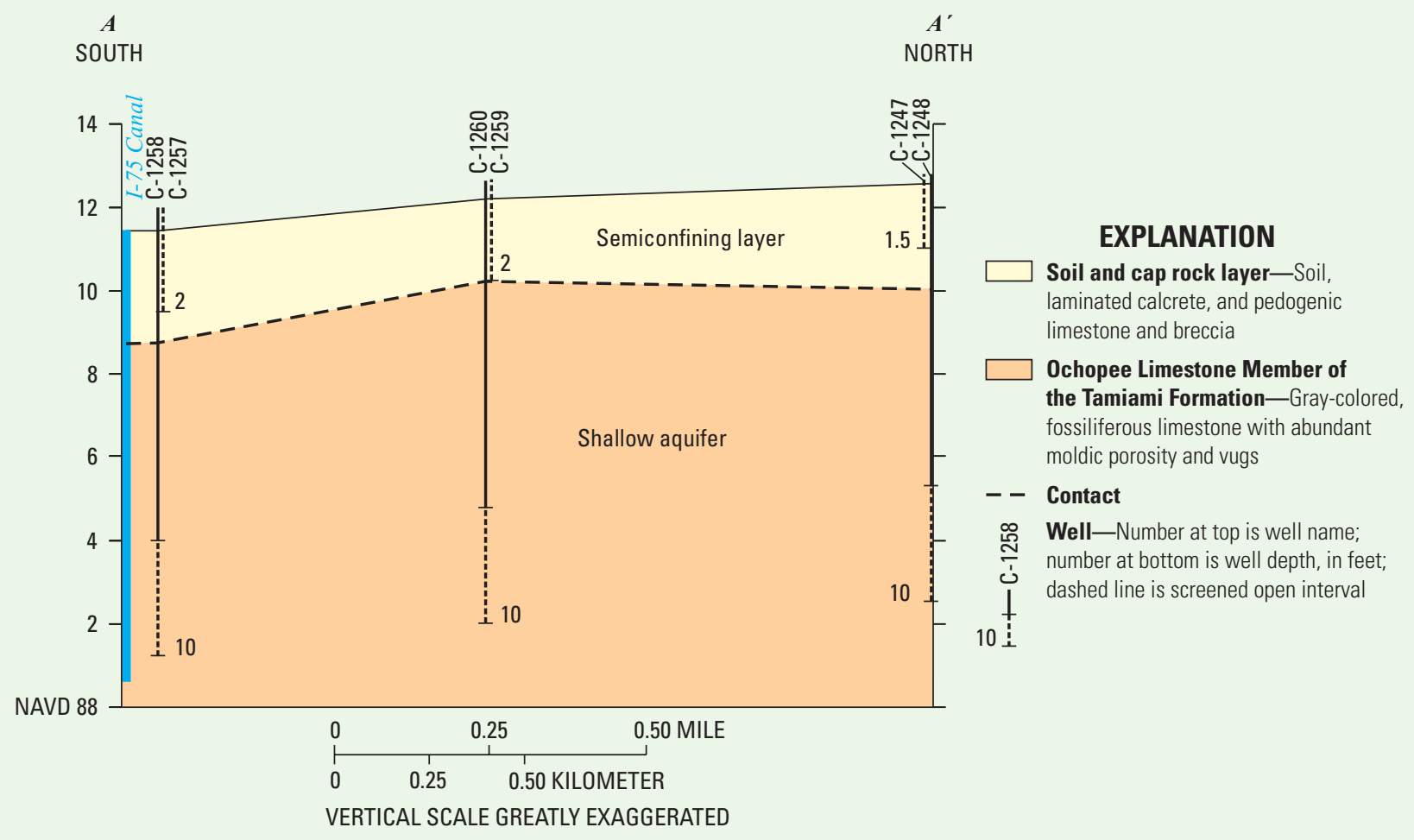

Figure 2. Hydrogeologic section $A-A^{\prime}$. Line of section shown in figure 1.

until November 2007. Transducers were not installed in C-1260, C-1254, and C-1250 until November 2006, April 2007, and November 2007, respectively. Transducers were not installed or working properly in the two deep wells in the southeastern part of the FPNWR (C-1262 and C-1264) until early 2007. Although a transducer was also installed in the shallow well at one site (C-1257), shallow wells at most other sites were never instrumented because these wells went dry after the wet season of 2006 . The last field trip made to download data was on November 20, 2007, and the transducers were left in the wells to continue to collect data.

\section{Hydrogeology}

The nature of the shallow hydrogeology in the FPNWR controls the exchange between surface water and groundwater. Depending on location, the geologic formations exposed at or near the land surface are either the Tamiami Formation of Pliocene age or undifferentiated shelly sediments of Pliocene to Pleistocene age (Scott and others, 2001). In a test well located near the southeastern corner of the FPNWR and the intersection of Interstate 75 (I-75) and State Road 29 (S.R. 29), a permeable limestone interval was mapped as the unconfined gray limestone aquifer from 5 to $70 \mathrm{ft}$ below land surface. This interval was included in the Ochopee Limestone Member of the Tamiami Formation by Reese and Cunningham (2000). Petrographic analyses of core samples from both sites in the southeastern corner of the FPNWR (fig. 1) indicate that the Pinecrest Sand Member of the Tamiami Formation is present from land surface to 3 to $5 \mathrm{ft}$ below land surface and unconformably overlies the Ochopee Limestone Member (L.J. Florea, U.S. Geological Survey, written commun., 2006). At the sites in the southwestern part of the FPNWR, however, only the Ochopee Limestone Member is present below a soil/ cap rock layer and extends downward to the total depth of the wells (fig. 2).
Although soil thickness averaged less than $1.5 \mathrm{ft}$, a pedogenically altered limestone layer was encountered from the base of the soil zone downward to a depth of about 2 to $3 \mathrm{ft}$ below land surface at most sites. This layer, which can be referred to as cap rock, contains several inches of laminated calcrete near its top at five of the cored sites. Cap rock at the top of the Tamiami Formation and at, or near, the land surface is common in the Big Cypress National Preserve to the east of the FPNWR (Duever and others, 1979). At most sites, a zone of lost circulation was encountered below this cap rock layer during drilling, indicating increased permeability. The high permeability of this zone and deeper, down to total depth of the wells, is due to abundant moldic and vuggy porosity present in the Ochopee Limestone Member.

Although the near-surface cap rock layer contains dense impermeable limestone, the unit should be referred to as semiconfining rather than confining because field observations indicate 


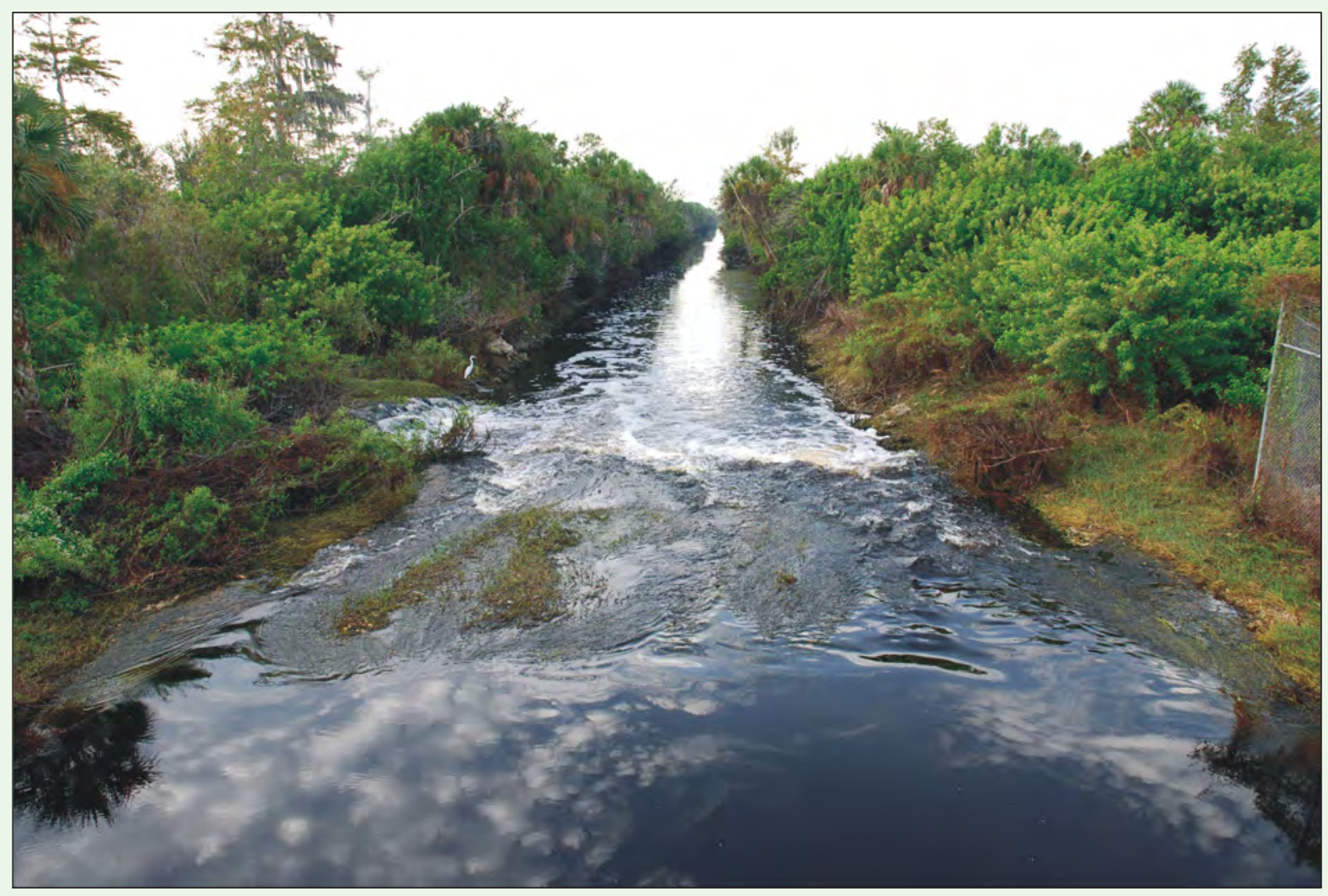

Figure 3. Surface-water flow in Merritt Canal looking downstream from I-75. Photograph by Roy Sonenshein, USGS.

the layer is pierced by epikarst features, such as fractures with dissolution, solution pipes, and soil-filled pits. The vertical permeability of this unit and the overlying soil zone is probably also quite variable because of differences in vegetation or ecological zones (cypress strand, pond, prairie, and pineland). In the pinelands, tree roots can penetrate, disrupt, and push up the bedrock surface or cap rock (Duever and others, 1979), whereas in pond or prairie areas, a thick, well-developed soil zone with organic matter and fine-grained sediment may impede vertical flow.

\section{Surface-Water Flows}

Before canal and highway construction, surface water within the FPNWR area flowed unimpeded to the west from East Hinson Marsh and Okaloachoochee Slough, curved southward into Fakahatchee Strand, and continued toward the south (fig. 1). Flow has been reduced or diverted by the construction of S.R. 29 and the associated Barron River
Canal along the eastern boundary of the FPNWR, and by I-75 and the associated borrow canal along the southern refuge boundary (fig. 1).

Three bridges along S.R. 29 allow surface water to flow from the Barron River Canal into the FPNWR (fig. 1). A small berm between the canal and bridges, however, prevents or restricts flow from the canal into the FPNWR, except during high-water conditions. The canal continues to the south along the east side of Fakahatchee Strand and acts as a drain that channels water southward.

Much of the surface water that flows into the FPNWR probably exits southward through Fakahatchee Strand as it did prior to development, because culverts and bridges constructed along I-75 allow overland flow to continue southward within the strand. During the dry season and periods of low water levels, however, much of the water is diverted by the I-75 Canal along the north side of I-75 (fig. 1). This canal drains to the west and to the south through Merritt Canal (fig. 3), which begins near the southwestern corner of the FPNWR. The hydraulic connection between Merritt Canal and the I-75 Canal is restricted by two earthen berms in Merritt Canal just north and south of I-75, but water was observed to flow over the berms during much of the year.

Discharge measurements were made on October 16-17, 2006, to compare inflows with outflows for the FPNWR during the early part of the dry season. Inflow to the FPNWR was 26 cubic feet per second $\left(\mathrm{ft}^{3} / \mathrm{s}\right)$, which was measured under the middle bridge along S.R. 29 (fig. 1) - the only bridge of the three with measurable flow. Estimated southward outflows in the Fakahatchee Strand area totaled $78 \mathrm{ft}^{3} / \mathrm{s}$, based on measurements made in the nine north-south culverts along I-75 (fig. 1); only the six westernmost culverts had measurable flow. Westward outflow from the FPNWR through the east-west culvert in the I-75 


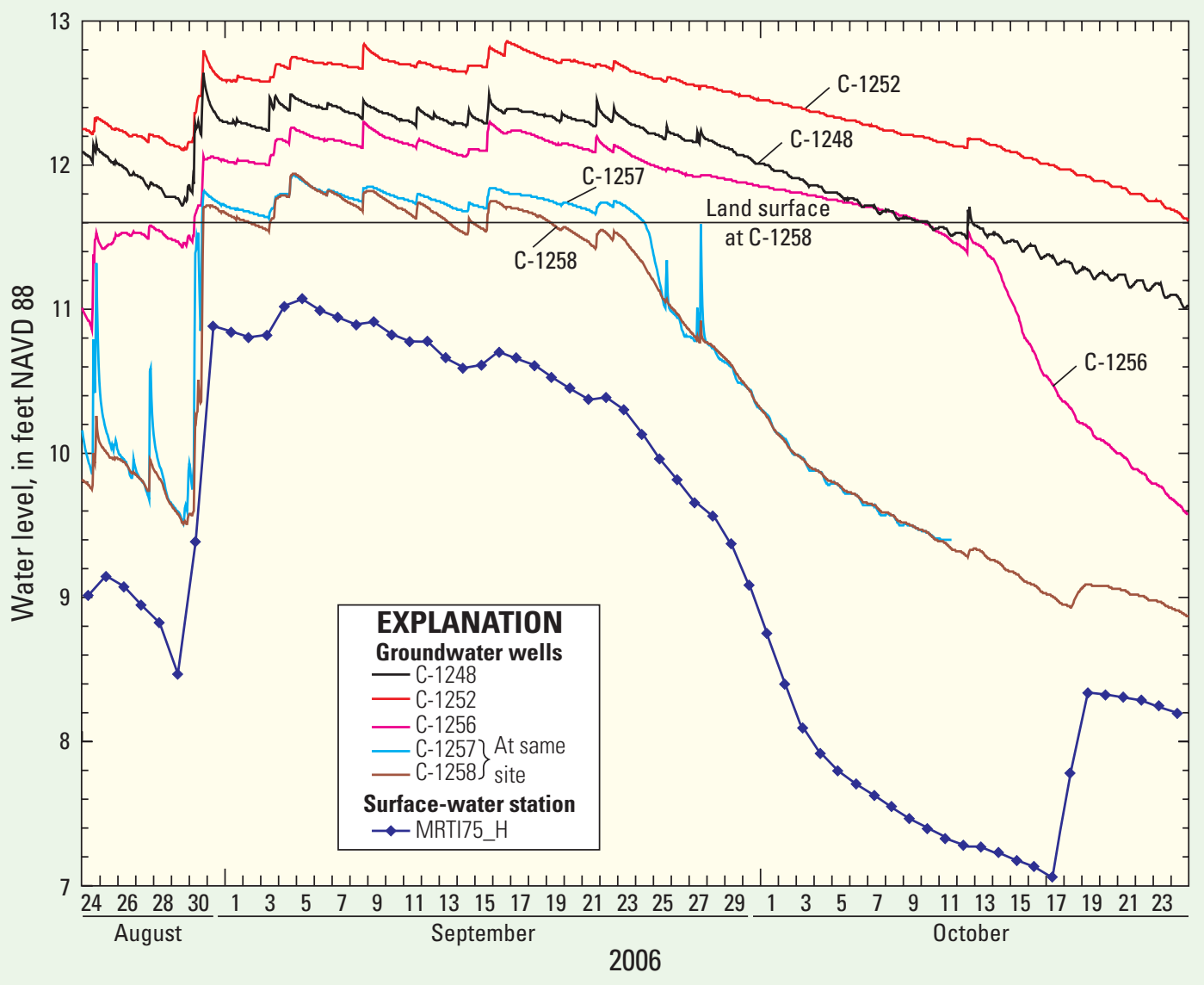

Figure 4. Water levels at a surface-water station and selected groundwater wells in the southwestern part of the Florida Panther National Wildlife Refuge from August to October 2006. Plotted groundwater and surface-water levels represent hourly readings and daily means, respectively.

Canal north of I-75 (fig. 1) was measured to be $36 \mathrm{ft}^{3} / \mathrm{s}$, and southward outflow in Merritt Canal at I-75 was measured to be $67 \mathrm{ft}^{3} / \mathrm{s}$. Overall, outflows were greater than inflows and flow in the I-75 Canal increased to the west, indicating there was substantial groundwater discharge from the FPNWR into the canal. Outflow measurements were again attempted on November 1, 2006, but the only point where flow was great enough to be measured was in Merritt Canal at I-75.

\section{Groundwater Levels and Surface- Water/Groundwater Interactions}

Groundwater levels in the FPNWR during the August 2006 to November 2007 monitoring period were affected by drought conditions. Rainfall for the nearby Big Cypress National Preserve during the October 2006 to September 2007 water year ${ }^{1}$ was about 9 inches (in.) below the long-term average of 54 in., based on South Florida Water Management District weather data (Bob Sobczak,
Big Cypress National Preserve, written commun., 2010). Additionally, rainfall was below average for three consecutive south Florida water years (May 1 to April 30) from 2006 through 2008. Groundwater levels in wells were above land surface at most measurement sites in the study area during late August and September 2006, but subsequently receded and did not rise above land surface again for the remainder of the monitoring period. Groundwater levels within the FPNWR began to decline in late September 2006 (fig. 4), which is earlier than the typical mid- to late-October date for the beginning of the dry season. Although the wet season generally begins in May, groundwater levels did not increase again until June 2007, and a large increase did not occur until August 2007 (fig. 5).

Surface-water drainage through Merritt Canal, resulting from the operation of a control structure south of the I-75 Canal, can substantially affect groundwater levels within the FPNWR. At the end of the 2006 wet season, a decline in groundwater levels in monitoring well C-1258 near the I-75 Canal paralleled the decline in surface-water levels in Merritt Canal at station MRTI75_H (fig. 1) due to the lowering of water levels in the canal during September and early October 2006 (fig. 4). Levels in C-1258 began a steep decline on September 23, 2006. Prior to this decline, and for 1 to 2 days afterward, water levels in shallow well C-1257 at the same site were above land surface and higher than in $\mathrm{C}-1258$ by 0.2 to $0.3 \mathrm{ft}$; they also declined at a lower rate than water levels in the deep well. This indicates some effect from the semiconfining unit separating shallow and deep monitoring wells. On September 24, however, water levels in the shallow well began to decline rapidly, and by the end of September 25 were nearly identical to water levels in the deep well. This greater rate of decline began when C-1257 water levels reached land surface (fig. 4). The rapid decline in C-1258 water levels may have begun when the water level in the canal dropped below the level 


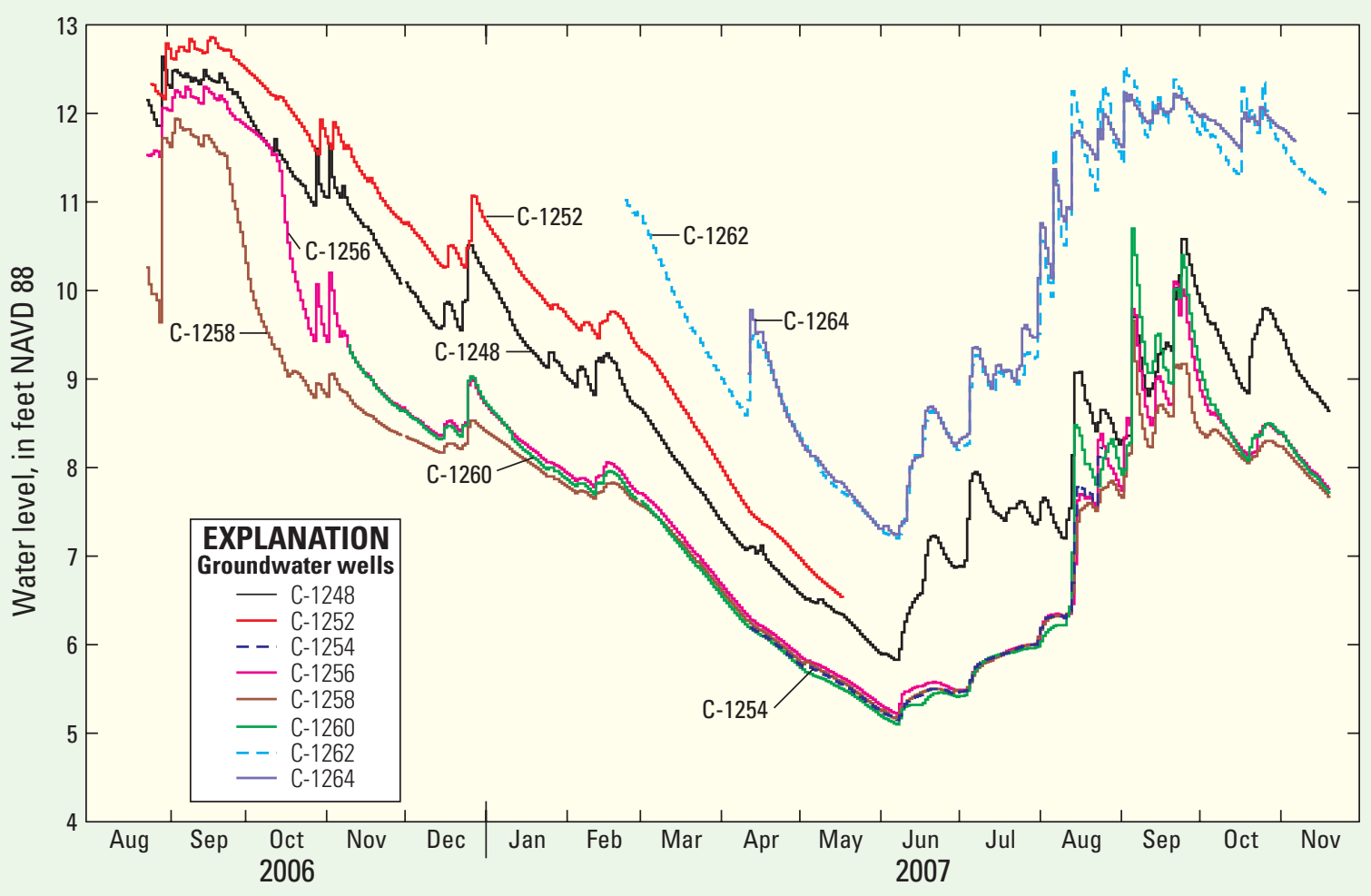

Figure 5. Water levels at all deep groundwater wells with data collected for the monitoring period of the study. Data shown are maximum daily water levels.

of the soil/cap rock layer in the north bank of the I-75 Canal (fig. 2). Water levels at station MRTI75_H decreased to $1.3 \mathrm{ft}$ below land surface at C-1258 on September 23 (fig. 4) and more than $3 \mathrm{ft}$ below this altitude by October 2 .

The gradual rate of water-level decline in wells during September and October 2006 was caused by surfacewater ponding at some sites. Water levels in deep wells at three sites north of the 1-75 Canal and farther into the FPNWR (C-1248, C-1252, and C-1256) declined at a more gradual rate than in $\mathrm{C}-1258$ during late September and October 2006 (fig. 4). Water levels in the well at the next closest site to the canal (C-1256), however, declined rapidly, beginning on October 14 when water levels declined below land-surface (fig. 4). This timing and rate of decline in $\mathrm{C}-1256$ is similar to those exhibited at the C-1258/C-1257 site as previously discussed. The more gradual decline in levels in C-1248 and C-1252 continued after water levels decreased below land surface at these sites, perhaps because of the greater distance of these sites from the canal.

Drainage of areas with ponded surface water may be delayed because of the time needed for water to recharge the aquifer and flow to the canal where it is discharged. Compared to predeveloped conditions, however, the time required to drain wetlands in some areas should be less because of the increased groundwater gradient and discharge caused by the lowering of water levels in the canal.

by Ronald S. Reese

\section{References Cited}

Duever, M.J., Carlson, J.E., Meeder, J.F., and others, 1979, The Big Cypress National Preserve: National Audubon Society Research Report no. 8, National Audubon Society, New York, 444 p. (Reprinted 1986.)

Reese, R.S., and Cunningham, K.J., 2000, Hydrogeology of the gray limestone aquifer in southern Florida: U.S. Geological Survey Water-Resources Investigations Report 99-4213, 244 p.

Scott, T.M, Campbell, K.M., Rupert, F.R., and others, 2001, Geologic map of the State of Florida: Florida Geological Survey, Florida Department of Enviromental Protection, $1 \mathrm{pl}$.
For further information, contact: U.S. Geological Survey, Florida Water Science Center, 3110 S.W. 9th Ave.,

Ft. Lauderdale, FL, 33315, http://fl.water.usgs.gov
For more information on the USGS-the Federal source for science about the Earth, its natural and living resources, natural hazards, and the environment: World Wide Web: http://www.usgs.gov Telephone 1-888-ASK-USGS
Any use of trade, product or firm names is for descriptive purposes only and does not imply endorsement by the U.S. Government
ISBN $978-7,-47,3-3028-3$

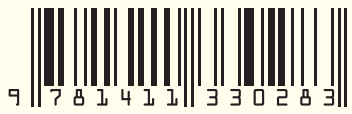

